\title{
Botulinum toxin for hereditary spastic paraplegia: effects on motor and non-motor manifestations
}

\author{
Toxina botulínica nas paraplegias espásticas hereditárias: efeitos nas manifestações \\ motoras e não-motoras
}

Katiane R. Servelhere', Ingrid Faber ${ }^{1}$, Alberto Martinez', Renato Nickel'2, Adriana Moro², Francisco M. B. Germiniani², Mariana Moscovich², Tatiane R. Blume², Renato P. Munhoz², Hélio A. G. Teive ${ }^{2}$, Marcondes C. França Jr ${ }^{1}$

\begin{abstract}
Motor and non-motor manifestations are common and disabling features of hereditary spastic paraplegia (HSP). Botulinum toxin type A (Btx-A) is considered effective for spasticity and may improve gait in these patients. Little is known about the effects of Btx-A on non-motor symptoms in HSP patients. Objective: To assess the efficacy of Btx-A on motor and non-motor manifestations in HSP patients. Methods: Thirty-three adult patients with a clinical and molecular diagnosis of HSP were evaluated before and after Btx-A injections. Results: Mean age was $41.7 \pm 13.6$ years and there were 18 women. Most patients had a pure phenotype and SPG 4 was the most frequent genotype. The Btx-A injections resulted in a decrease in spasticity at the adductor muscles, and no other motor measure was significantly modified. In contrast, fatigue scores were significantly reduced after Btx-A injections. Conclusion: Btx-A injections resulted in no significant functional motor improvement for HSP, but fatigue improved after treatment.
\end{abstract}

Keywords: botulinum toxin; spastic paraplegia, hereditary; muscle spasticity.

\section{RESUMO}

Manifestações motoras e não motoras são comuns e incapacitantes nas paraparesias espásticas hereditárias (PEH). Toxina botulínica do tipo A (TB-A) é considerada eficaz no tratamento da espasticidade e pode melhorar a marcha nesses pacientes. Pouco se sabe sobre os efeitos da TB-A sobre sintomas não-motores. Objetivo: avaliar a eficácia da TB-A sobre manifestações motoras e não-motoras nas PEH. Método: trinta e três pacientes adultos com PEH foram avaliados antes e depois das aplicações de TB-A. Resultados: A média de idade foi 41,7 $\pm 13,6$ anos e havia 18 mulheres. A maioria dos pacientes portava a forma pura e o genótipo mais comum foi SPG4. Houve diminuição da espasticidade dos músculos adutores da coxa sem melhora da marcha. A pontuação da fadiga reduziu após as injeções. Conclusão: As aplicações de TB-A não melhoraram a marcha nos pacientes mas a redução da fadiga foi significativa após o tratamento.

Palavras-chave: toxinas botulínicas; paraparesia espástica hereditária; espasticidade muscular.

\section{INTRODUCTION}

Hereditary spastic paraplegia (HSP) comprises a heterogeneous group of neurodegenerative disorders characterized by slowly progressive spasticity and variable degrees of weakness, predominantly in the lower $\operatorname{limbs}^{1,2}$. Hereditary spastic paraplegia is classified as pure or complicated, depending on the presence of additional signs or symptoms. Currently there are more than 70 different disease-loci and 50 spastic paraplegia genes (SPGs) ${ }^{2.3}$.
Management of spasticity in HSP using botulinum toxin injections type A (Btx-A) has been described in some studies ${ }^{4,5,6,7,8}$. An injection of Btx-A is considered effective and safe for the treatment of lower limb spasticity in adults ${ }^{4,6,8,9,10}$ and children $^{5}$. Some studies have found that, in general, Btx-A combined with physiotherapy improves comfortable gait velocity ${ }^{4,6,8}$ in HSP patients, but it is not yet known whether Btx-A improves non-motor manifestations in these patients. Non-motor manifestations are common complaints in HSP

1 Universidade Estadual de Campinas, Hospital de Clínicas, Departamento de Neurologia, Campinas SP, Brasil;

¿Universidade Federal do Paraná, Hospital de Clínicas, Departamento de Medicina Interna, Serviço de Neurologia, Unidade de Distúrbios do Movimento, Curitiba PR, Brasil.

Correspondence: Marcondes Cavalcante França Jr.; Departamento de Neurologia da UNICAMP; Rua Tessália Vieira de Camargo, 126 ; $13083-887$ Campinas SP, Brasil; E-mail:mcfrancajr@uol.com.br

Support: This study was supported by research grants from FAPESP and CAPES.

Conflict of interest: There is no conflict of interest to declare.

Received 31 May 2017; Received in final form 16 November 2017; Accepted 18 December 2017. 
patients and, in many cases, more disabling than the motor handicap per se. They include fatigue, pain, excessive daytime sleepiness and depression. In a recent study, Servelhere et al. found that $73.3 \%$ of patients with HSP caused by SPG4 mutations had pain and $36.6 \%$ had depression ${ }^{11}$. Despite this significant clinical burden, much remains to be investigated on the optimal management of these manifestations.

Therefore, the aim of this study was to evaluate the efficacy of Btx-A injections, not only for motor, but also for nonmotor manifestations in HSP patients. To accomplish that, we performed a comprehensive evaluation using a panel of validated clinical scales in patients with pure and complicated forms of HSP before and after treatment.

\section{METHODS}

\section{Patients}

Thirty-three adult patients with clinical and molecular diagnoses of HSP from two Brazilian centers [Federal University of Paraná (UFPR) and University of Campinas (UNICAMP)] were evaluated before and after administration of Btx-A from February 2013 to December 2014. Patients with concomitant neurological disorders and those younger than 15 years were excluded. This research protocol was approved by each institution's research ethics committee and a written informed consent was obtained from all patients. For each subject, we collected data on gender, age, age at onset, phenotype, genotype, inheritance pattern and interval between examinations (Table 1).

Table 1. Demographic and clinical data of patients with hereditary spastic paraplegia included in this study.

\begin{tabular}{|c|c|c|c|}
\hline Variable & $\begin{array}{l}\text { Unicamp } \\
(\mathrm{n}=22)\end{array}$ & $\begin{array}{l}\text { UFPR } \\
(n=11)\end{array}$ & $\begin{array}{l}\text { TOTAL } \\
(n=33)\end{array}$ \\
\hline Gender (M/F) & $12 / 10$ & $3 / 8$ & $15 / 18$ \\
\hline \multicolumn{4}{|l|}{ Phenotype } \\
\hline Pure (\%) & $\begin{array}{c}15 \\
(68.1 \%)\end{array}$ & $\begin{array}{c}11 \\
(100 \%)\end{array}$ & $\begin{array}{c}26 \\
(78.7 \%)\end{array}$ \\
\hline Complicated (\%) & $\begin{array}{c}7 \\
(31.8 \%)\end{array}$ & $\begin{array}{c}0 \\
(0 \%)\end{array}$ & $\begin{array}{c}7 \\
(21.2 \%)\end{array}$ \\
\hline \multicolumn{4}{|l|}{ Inheritance pattern } \\
\hline Autosomal dominant (\%) & $\begin{array}{c}15 \\
(68.1 \%)\end{array}$ & $\begin{array}{c}11 \\
(100 \%)\end{array}$ & $\begin{array}{c}26 \\
(78.7 \%)\end{array}$ \\
\hline Autosomal recessive (\%) & $\begin{array}{c}6 \\
(27.2 \%)\end{array}$ & $\begin{array}{c}0 \\
(0 \%)\end{array}$ & $\begin{array}{c}6 \\
(18.1 \%)\end{array}$ \\
\hline \multicolumn{4}{|l|}{ Genotype } \\
\hline SPG4 (\%) & $\begin{array}{c}8 \\
(36.3 \%)\end{array}$ & $\begin{array}{c}7 \\
(63.6 \%)\end{array}$ & $\begin{array}{c}15 \\
(45.4 \%)\end{array}$ \\
\hline SPG11 (\%) & $\begin{array}{c}2 \\
(9.0 \%)\end{array}$ & $\begin{array}{c}0 \\
(0 \%)\end{array}$ & $\begin{array}{c}2 \\
(6.0 \%)\end{array}$ \\
\hline Other (\%) & $\begin{array}{c}12 \\
(54.5 \%)\end{array}$ & $\begin{array}{c}4 \\
(36.3 \%)\end{array}$ & $\begin{array}{c}16 \\
(48.4 \%)\end{array}$ \\
\hline Age (mean $\pm S D$, years) & $41.7 \pm 14.3$ & $41.5 \pm 12.8$ & $41.7 \pm 13.6$ \\
\hline Age at onset (mean $\pm S D$, years) & $21.9 \pm 16.0$ & $23.5 \pm 16.2$ & $22.4 \pm 15.8$ \\
\hline $\begin{array}{l}\text { Interval between examinations } \\
\text { (mean } \pm \text { SD, years) }\end{array}$ & $44.5 \pm 17.5$ & 30 & $39.7 \pm 15.8$ \\
\hline
\end{tabular}

\section{Motor and non-motor evaluations}

In order to evaluate the effects of Btx-A, we employed a comprehensive panel of instruments that assessed both motor and non-motor manifestations. All scales were validated for Brazilian Portuguese. We used three motor assessment tools for the whole sample: the Medical Research Council scale ${ }^{12}$ to evaluate muscle strength on the ankle dorsiflexors and hip abductors; the Modified Ashworth Scale ${ }^{13}$ to evaluate spasticity of the triceps surae and adductor muscles; and the 10-meter walk test ${ }^{14}$, a stop watch measure of walking speed for a standardized distance of ten meters. For those patients who scored in the range " $1+$ " on the Ashworth scale, we considered quantification of 1.5. Gait velocity $(\mathrm{m} / \mathrm{s})$ was evaluated in a straight line, in comfortable conditions, with shoes and gait aid devices if necessary.

In addition, we were able to collect information on nonmotor symptoms for a subset of 22 patients. Five assessment tools were used for these patients: the Spastic Paraplegia Rating Scale ${ }^{15}$, Epworth Sleepiness Scale ${ }^{16}$; the Modified Fatigue Impact Scale ${ }^{17}$, Beck Depression Inventory ${ }^{18}$ and Brief Pain Inventory ${ }^{19}$. We also included a single item from the Spastic Paraplegia Rating Scale concerning pain. The Epworth Sleepiness Scale, Beck Depression Inventory and Modified Fatigue Impact Scale were considered abnormal if scores were higher or equal to 9,11 and 38 respectively ${ }^{16,17,18}$.

\section{Btx-A injections}

All patients were given intramuscular injections of Btx-A (Dysport $500 \mathrm{IU}$ ) using palpatory anatomy as a means of guidance for administration. The doses and muscles to be injected were determined by the treating physicians after careful evaluation of the gait, strength and spasticity pattern of each patient. The evaluators were not aware of the injection protocol for the duration of the study. We opted to use this approach in order to simulate a realistic clinical scenario, taking into account that each individual had a specific profile of motor abnormalities (extent and severity of spasticity).

Twenty-two patients came from UNICAMP and received Btx-A injections with a mean total dosage of $1,110.0 \pm 435.1$ units. Of these, 19 patients received Btx-A injections in the gastrocnemius (mean dose $341.0 \pm 98.9$ units) and adductor muscles (mean dose $488.4 \pm 165.7$ ); 11 in the soleus (mean dose $145.4 \pm 35.8$ ), eight in the hamstrings (mean dose $402.5 \pm 146.7$ ), six in the tibialis posterior (mean dose $130.0 \pm 64.1$ ), five in the quadriceps (mean dose $356.0 \pm 126.8$ ), three in the extensor hallucis longus (mean dose 106.6 \pm 23.0 ), and two in the flexor digitorum longus (mean dose $130.0 \pm 14.1$ ) and brevis (mean dose $120.0 \pm 0$ ). Only one patient received Btx-A injections in the flexor hallucis brevis (80 units), quadratus lumborum (200 units) and tibialis anterior (220 units). All the patients coming from UFPR ( $\mathrm{n}=11$ ) received Btx-A injections in the gastrocnemius (mean dose $200 \pm 44.7$ units), eight in adductor muscles (mean dose $181.2 \pm 59.3$ units), one patient in the soleus muscle (50 units) and one in the tibialis posterior (100 units). The mean total dose for the 11 patients from UFPR was $345.4 \pm 131.2$ units. 


\section{Statistical analyses}

Descriptive variables were expressed as mean and standard deviation. The Kolmogorov-Smirnov test was used to assess whether the data had a normal distribution. We then performed the Wilcoxon signed-rank test to compare the results of motor and non-motor scales before and after Btx-A injections. The level of significance was set at $p=0.05$ for all analyses. The SPSS v 21 (IBM SPSS Statistics) was used for all statistical analyses.

\section{RESULTS}

\section{Patients}

We assessed 33 patients from UFPR $(\mathrm{n}=11)$ and $\operatorname{UNICAMP}(\mathrm{n}=22)$ with a mean age of $41.7 \pm 13.6$ and age at onset of $22.4 \pm 15.8$ years. There were 18 women and 15 men. Most patients had a pure phenotype $(78.7 \%)$ and $S P G 4$ was the most frequent genotype (45.4\%). The mean interval between examinations was $39.7 \pm 15.8$ days (Table 1 ).

\section{Motor scores $(n=33)$}

The results of Btx-A injections on motor scores were conflicting. The main positive finding was a significant reduction of adductor spasticity $(1.8 \pm 1.2 \times 1.4 \pm 1.1, p=0.03)$, shown in Figure 1. When we compared pure and complicated HSP, no significant difference regarding motor parameters emerged.

Twenty-seven patients received Btx-A injections in hip adductor muscles. Of these, 12 patients (44.4\%) had improvement: seven patients (25.9\%) had a 1-point improvement; one had a 1.5-point improvement; three had a 2-point and one had a 3-point improvement. Eleven patients kept the same score and four patients had an increase of one point. After the injections, there was no significant change in terms of spasticity of the triceps surae, muscle strength of the hip

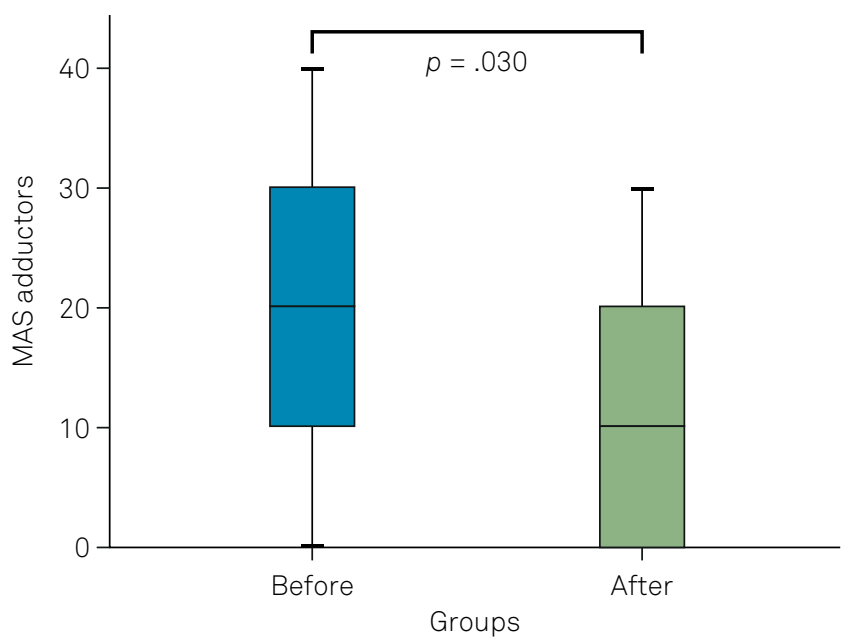

MAS: Modified Ashworth scale.

Figure 1. Box and whiskers plot showing Ashworth scores for the hip adductors before (left) and after (right) Btx-A injections. abductor and ankle dorsiflexors muscles and the 10-meter walk test (Table 2).

\section{Non-motor scores $(n=22)$}

We found a significant reduction of fatigue after Btx-A injections, as shown in Figures 2 and 3.

Table 2. Motor features before and after botulinum toxin injections in patients with hereditary spastic paraplegia $(n=33)$.

\begin{tabular}{lccc}
\hline Variable & Before & After & p-value \\
\hline MRC abductor muscles & $3.9 \pm 0.9$ & $3.9 \pm 0.9$ & 0.782 \\
MRC ankle extensor muscles & $4.1 \pm 0.9$ & $4.1 \pm 0.9$ & 0.739 \\
Tone adductor muscles (MAS) & $1.8 \pm 1.2$ & $1.4 \pm 1.1$ & $0.030 *$ \\
Tone triceps surae muscles (MAS) & $2.1 \pm 1.0$ & $1.9 \pm 1.1$ & 0.243 \\
Walking time 10 meters & $25.6 \pm 18.124 .3 \pm 18.5$ & 0.328 \\
\hline Both patients followed at UNICAMP and UFPR are reported. aall values are \\
expressed as mean and SD. MRC: Medical Research Council scale; MAS:
\end{tabular}

modified Ashworth scale.

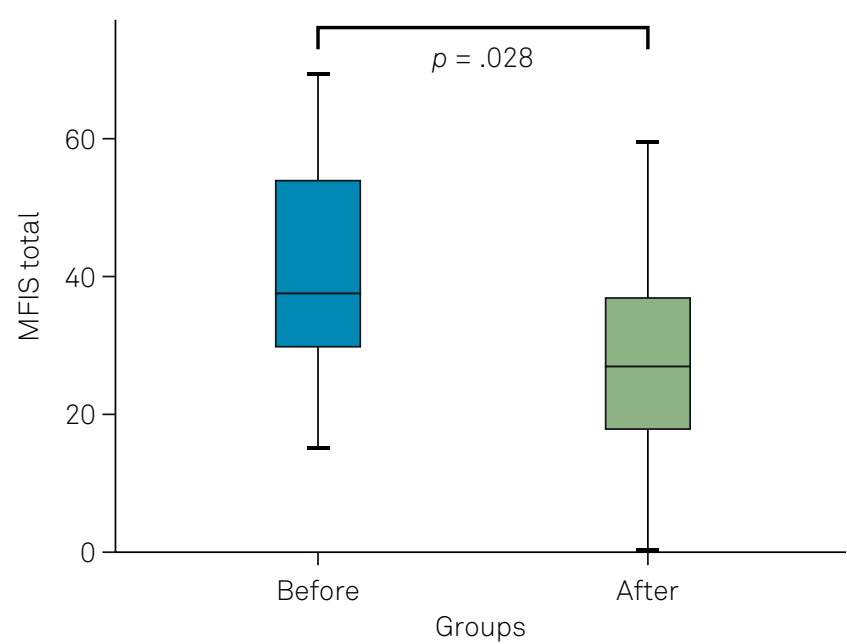

MFIS: Modified fatigue impact scale.

Figure 2. Box and whiskers plot showing MFIS scores for fatigue before (left) and after (right) Btx-A injections.

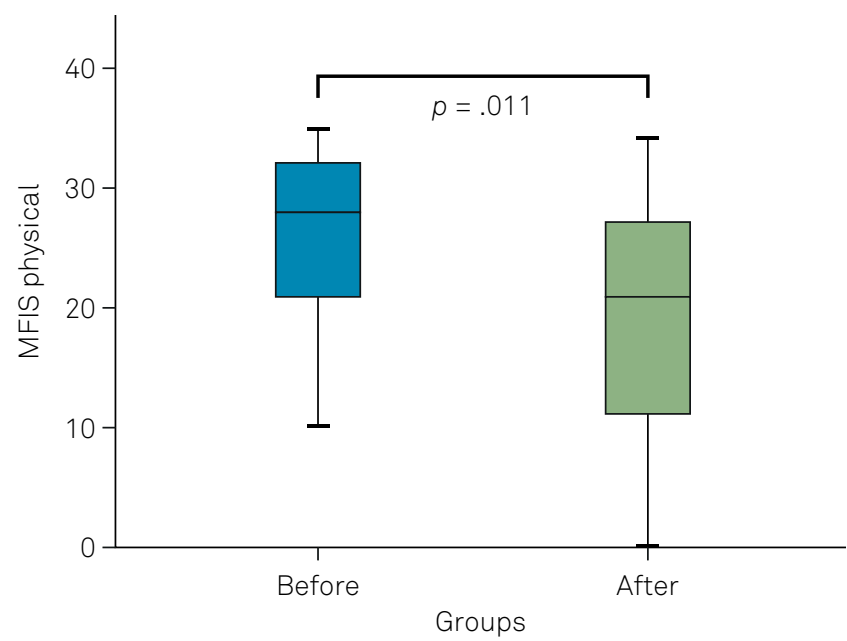

MFIS: Modified fatigue impact scale.

Figure 3. Box and whiskers plot showing MFIS scores for physical fatigue subset before (left) and after (right) Btx-A injections. 
There was an improvement, not only in the physical fatigue subset ( $25.4 \pm 7.8$ vs $19.2 \pm 9.6 ; \mathrm{p}=0.011)$, but also of the total fatigue score $(39.5 \pm 14.7$ vs $28.3 \pm 15.7$; $\mathrm{p}=0.028)$ (Table 3). Interestingly, we verified that physical fatigue (on the Modified Fatigue Impact Scale physical subset) improved after Btx-A injections only in pure forms $(p=0.03)$ but not in complicated forms $(\mathrm{p}=0.2)$.

There was no difference in the cognitive and psychosocial subsets of the Modified Fatigue Impact Scale, daytime sleepiness, depression and pain before and after Btx-A. This lack of difference was evident in the comparison between pure and complicated HSPs.

\section{Side effects}

Two patients from UNICAMP had side effects after Btx-A injections. One reported an inability to stand up and walk, slurred speech, motor slowness and handwriting incoordination 14 days after Btx-A injections. The other patient complained about excessive sleepiness, dizziness, swollen legs, and blurred vision. None of these complaints lasted longer than six months.

\section{DISCUSSION}

Botulinum toxin type A has been considered effective in treating leg spasticity muscles in different neurological disorders $^{20,21}$. Regarding HSPs in particular, some studies have reported variable degrees of improvement in spasticity and functional capacities, such as gait velocity ${ }^{4,5,6,7,8}$. In line with this, our study identified improvement in hip adductor spasticity as the main result in terms of motor manifestations. Surprisingly, there was no significant functional gain, as gait velocity remained stable between injections. This is in contrast to Rousseaux et al. ${ }^{6}$ and Niet et al. ${ }^{8}$, who found positive results with Btx-A in comfortable gait velocity, but not in maximum gait speed.

Table 3. Non-motor features before and after botulinum toxin applications in patients with hereditary spastic paraplegia $(n=22)$.

\begin{tabular}{lccc}
\hline Variable & Before & After & p-value \\
\hline SPRS $^{a}$ & $21.6 \pm 9.0$ & $21.4 \pm 9.1$ & 0.716 \\
\hline ESS & $3.6 \pm 3.7$ & $4.3 \pm 4.8$ & 0.835 \\
\hline MFIS physical & $25.4 \pm 7.8$ & $19.2 \pm 9.6$ & $0.011^{*}$ \\
\hline MFIS cognitive & $9.5 \pm 7.9$ & $5.5 \pm 7.2$ & 0.085 \\
\hline MFIS psychosocial & $4.5 \pm 2.9$ & $3.5 \pm 2.5$ & 0.311 \\
\hline MFIS total & $39.5 \pm 14.7$ & $28.3 \pm 15.7$ & $0.028^{*}$ \\
\hline BDI & $10.5 \pm 8.4$ & $10.2 \pm 9.0$ & 0.397 \\
\hline BPI intensity & $1.6 \pm 2.1$ & $2.4 \pm 2.5$ & 0.115 \\
\hline BPI interference & $1.5 \pm 2.1$ & $1.4 \pm 1.7$ & 0.724 \\
\hline SPRS 12 & $1.5 \pm 1.5$ & $1.3 \pm 1.4$ & 0.476 \\
\hline
\end{tabular}

Only patients followed at UNICAMP are reported; all values are expressed as mean and SD.SPRS:Spastic Paraplegia Rating Scale;ESS:Epworth Sleepiness Scale; MFIS: modified fatigue impact scale; BDI: Beck depression inventory; BPI: brief pain inventory; SPRS12: a single item from the SPRS concerning pain.
Several points should be considered to clarify these differences. Firstly, different injection protocols were performed. Moreover, there was a distinct profile of the patients in each study: Rousseaux et al. and Niet et al. ${ }^{8}$ included only patients with pure HSP and their cohorts were slightly older than ours. Other possible reasons for the negative results in the current study are the relatively low doses used and the restricted injection protocol, which included only a few muscles for each patient. Perhaps, in future studies, we could use more detailed techniques (such as gait analysis) to determine more precisely the doses and muscles to be injected in each individual. Finally, we could not ascertain whether all patients performed physical therapy on a regular basis. It is well known that the combination of Btx-A and rehabilitation significantly improves the therapeutic results. For some patients, the lack of improvement may have been due to nonadherence to the physical therapy program.

The major contribution of this study was the assessment of the effects of Btx-A on HSP-related non-motor manifestations. To the best of our knowledge, there are no studies that have looked at this specific point. We indeed found a significant improvement of fatigue after treatment, especially its physical domain. Fatigue is considered as tiredness or lack of energy ${ }^{17}$, and might be caused by extreme gait effort during locomotion in HSP. We hypothesize that Btx-A relieves spasticity, improves the biomechanics of gait and, therefore, improves fatigue in these subjects. When we analyzed pure and complicated forms separately, no significant differences regarding motor symptoms between groups were present. However, there was a significant difference before and after injections with respect to physical fatigue (Modified Fatigue Impact Scale physical subset) for pure forms only. A possible explanation may rely upon the fact that cognitive impairment is much more common in complicated forms of spastic paraplegia genes ${ }^{22}$, and this difference in fatigue may be related to a recall bias or even a distinct perception of fatigue in the cognitively-impaired subgroup of complicated HSPs.

Pain is another important and frequent non-motor feature of HSP, affecting $73.3 \%$ of patients ${ }^{11}$. Treatment of HSPrelated pain is an unmet medical need, and further studies on the topic are needed. The analgesic effects of Btx-A have increasingly been recognized in several chronic pain syndromes, such as migraine and other headaches ${ }^{23}$. In addition, a recent French, double-blind, randomized and placebocontrolled study showed the safety and efficacy of repeated administrations of Btx-A in patients with neuropathic pain ${ }^{24}$. Surprisingly, we were not able to demonstrate significant pain improvement after Btx-A injections. One possible explanation is that this cohort was largely pain-free (mean Brief Pain Inventory intensity score $<2$ ), so that identification of further improvement was difficult ( floor effect). Additionally, injection protocols were different for each patient in terms of doses and injection sites. We believe that some patients 
may have improved, whereas others may not have. In grouping all the patients together, we may have lost statistical significance on these effects.

This is perhaps the largest study to report the effects of Btx-A on HSP, but we acknowledge that it still has some important limitations. Firstly, there was no specific Btx-A injection protocol; we left the choice of doses and sites to the evaluating physicians. Although this may have introduced bias in the final analyses, we chose to perform an open uncontrolled study in order to reproduce a realistic clinical scenario, thus generating a study consistent with the daily practice of an outpatient clinic. A second limitation was the phenotypic heterogeneity of our cohort; most of the patients had pure HSP (78.7\%), but some of them displayed a complicated phenotype. All those with complicated HSP had spasticity as the major complaint, but three of them also had signs of peripheral nerve damage (two of whom had SPG11 mutations), a finding that might have interfered with the efficacy and safety of Btx-A.
In conclusion, we have shown, in a mixed cohort of HSP patients, that Btx-A injections provide some benefits, not only for spasticity, but also for fatigue. These results are in line with previous reports, but the real effects of Btx-A on physical functioning and quality of life remain unclear. Available studies have conflicting results, largely due to the heterogeneity of patients, assessment tools and injection protocols. Therefore, a well-designed, placebo-controlled trial with an adequate number of patients is urgently needed to determine definitively the role of Btx-A in the management of motor and nonmotor features of patients with HSP.

\section{ACKNOWLEGMENTS}

This study was supported by Fundação de Amparo à Pesquisa do Estado de São Paulo (FAPESP)2013/01766-7 and Coordenação de Aperfeiçoamento de Pessoal de Nível Superior CAPES

\section{References}

1. Fink JK. Hereditary spastic paraplegia: clinico-pathologic features and emerging molecular mechanisms. Acta Neuropathol. 2013 Sep;126(3):307-28. https://doi.org/10.1007/s00401-013-1115-8

2. Salinas S, Proukakis C, Crosby A, Warner TT. Hereditary spastic paraplegia: clinical features and pathogenetic mechanisms. Lancet Neurol. 2008 Dec;7(12):1127-38. https://doi.org/10.1016/S1474-4422(08)70258-8

3. Lo Giudice T, Lombardi F, Santorelli FM, Kawarai T, Orlacchio A. Hereditary spastic paraplegia: clinical-genetic characteristics and evolving molecular mechanisms. Exp Neurol. 2014 Nov;261:518-39. https://doi.org/10.1016/j.expneurol.2014.06.011

4. Hecht MJ, Stolze H, Auf dem Brinke M, Giess R, Treig T, Winterholler M et al. Botulinum neurotoxin type A injections reduce spasticity in mild to moderate hereditary spastic paraplegia: report of 19 cases. Mov Disord. 2008 Jan;23(2):228-33. https://doi.org/10.1002/mds.21809

5. Geva-Dayan K, Domenievitz D, Zahalka R, Fattal-Valevski A. Botulinum toxin injections for pediatric patients with hereditary spastic paraparesis. J Child Neurol. 2010 Aug;25(8):969-75. https://doi.org/10.1177/0883073809356037

6. Rousseaux M, Launay MJ, Kozlowski O, Daveluy W. Botulinum toxin injection in patients with hereditary spastic paraparesis. Eur J Neurol. 2007 Feb;14(2):206-12. https://doi.org/10.1111/j.1468-1331.2006.01617.x

7. Riccardo M, Angela L, Angela D, Vita P, Giulio L, Pietroq F et al. Combined Treatment Fkt-Botulinum Toxin Type A (Btx-A) in Patients with Strumpell-Lorrain Disease. Curr Pharm Des. 2016;22(6):758-63. https://doi.org/10.2174/1381612822666151204001830

8. Niet M, de Bot ST, van de Warrenburg BP, Weerdesteyn V, Geurts AC. Functional effects of botulinum toxin type-A treatment and subsequent stretching of spastic calf muscles: a study in patients with hereditary spastic paraplegia.J Rehabil Med. 2015 Feb;47(2):147-53. https://doi.org/10.2340/16501977-1909

9. Schulte-Mattler WJ. Use of botulinum toxin A in adult neurological disorders: efficacy, tolerability and safety. CNS Drugs. 2008;22(9):72538. https://doi.org/10.2165/00023210-200822090-00002

10. Muller F, Cugy E, Ducerf C, Delleci C, Guehl D, Joseph PA et al. Safety and self-reported efficacy of botulinum toxin for adult spasticity in current clinical practice: a prospective observational study. Clin Rehabil. 2012 Feb;26(2):174-9. https://doi.org/10.1177/0269215511412799

11. Servelhere KR, Faber I, Saute JA, Moscovich M, D’Abreu A, Jardim $L B$ et al. Non-motor symptoms in patients with hereditary spastic paraplegia caused by SPG4 mutations. Eur J Neurol. 2016 Feb;23(2):408-11. https://doi.org/10.1111/ene.12839

12. Compston A. Aids to the investigation of peripheral nerve injuries Medical Research Council: Nerve Injuries Research Committee. His Majesty's Stationery Office: 1942; pp. 48 (iii) and 74 figures and 7 diagrams; with aids to the examination of the peripheral nervous system. By Michael O'Brien for the Guarantors of Brain. Saunders Elsevier: 2010; pp. [8] 64 and 94 Figures. Brain. 2010 Oct;133(10):2838-44. https://doi.org/10.1093/brain/awq270

13. Bohannon RW, Smith MB. Interrater reliability of a modified Ashworth scale of muscle spasticity. Phys Ther. 1987 Feb;67(2):206-7. https://doi.org/10.1093/ptj/67.2.206

14. Rossier P, Wade DT. Validity and reliability comparison of 4 mobility measures in patients presenting with neurologic impairment. Arch Phys Med Rehabil. 2001 Jan;82(1):9-13. https://doi.org/10.1053/apmr.2001.9396

15. Schüle R, Holland-Letz T, Klimpe S, KassubekJ, Klopstock T, Mall V et al. The Spastic Paraplegia Rating Scale (SPRS): a reliable and valid measure of disease severity. Neurology. 2006 Aug;67(3):430-4. https://doi.org/10.1212/01.wnl.0000228242.53336.90

16. Bertolazi AN, Fagondes SC, Hoff LS, Pedro VD, Menna Barreto SS, Johns MW. Portuguese-language version of the Epworth sleepiness scale: validation for use in Brazil. J Bras Pneumol. 2009 Sep;35(9):87783. https://doi.org/10.1590/S1806-37132009000900009

17. Pavan K, Schmidt K, Marangoni B, Mendes MF, Tilbery CP, Lianza S. [Multiple sclerosis: cross-cultural adaptation and validation of the modified fatigue impact scale]. Arq Neuropsiquiatr. $2007 \mathrm{Sep} ; 65$ 3A:669-73. https://doi.org/10.1590/S0004-282X2007000400024

18. Gorenstein C, Andrade L. Validation of a Portuguese version of the Beck Depression Inventory and the State-Trait Anxiety Inventory in Brazilian subjects. Braz J Med Biol Res. 1996 Apr;29(4):453-7.

19. Ferreira KA, Teixeira MJ, Mendonza TR, Cleeland CS. Validation of brief pain inventory to Brazilian patients with pain. Support Care Cancer. 2011 Apr;19(4):505-11. https://doi.org/10.1007/s00520-010-0844-7 
20. Pauri F, Boffa L, Cassetta E, Pasqualetti P, Rossini PM.

Botulinum toxin type-A treatment in spastic paraparesis: a neurophysiological study.J Neurol Sci. 2000 Dec;181(1-2):89-97. https://doi.org/10.1016/S0022-510X(00)00439-1

21. Rousseaux M, Compère S, Launay MJ, Kozlowski O. Variability and predictability of functional efficacy of botulinum toxin injection in leg spastic muscles.

J Neurol Sci. 2005 May;232(1-2):51-7. https://doi.org/10.1016/j.jns.2005.01.009

22. Faber I, Branco LM, França Júnior MC. Cognitive dysfunction in hereditary spastic paraplegias and other motor neuron disorders. Dement Neuropsychol. 2016 Oct-Dec;10(4):276-9. https://doi.org/10.1590/s1980-5764-2016dn1004004

23. Shehata HS, Esmail EH, Abdelalim A, El-Jaafary S, Elmazny A, Sabbah A et al. Repetitive transcranial magnetic stimulation versus botulinum toxin injection in chronic migraine prophylaxis: a pilot randomized trial. J Pain Res. 2016 Oct;9:771-7. https://doi.org/10.2147/JPR.S116671

24. Attal N, Andrade DC, Adam F, Ranoux D, Teixeira MJ, Galhardoni R et al. Safety and efficacy of repeated injections of botulinum toxin $A$ in peripheral neuropathic pain (BOTNEP): a randomised, double-blind, placebo-controlled trial. Lancet Neurol. 2016 May;15(6):555-65. https://doi.org/10.1016/S1474-4422(16)00017-X 